\title{
THERMAL COATINGS PROPERTIES BY DUPLEX TECHNOLOGY
}

\author{
František VYSOUDIL ${ }^{1}$, Vladislav OCHODEK ${ }^{1}$, Jiří BÍLEK ${ }^{1}$ \\ ${ }^{1}$ VSB - Technical University of Ostrava, Department of Mechanical Technology, Czech Republic, EU, \\ frantisek.vysoudil.st@vsb.cz, vladislav.ochodek@vsb.cz, iiril.bilek.st@vsb.cz
}

https://doi.org/10.37904/metal.2021.4128

\begin{abstract}
The article deals with the production and evaluation of thermal spraying layers using duplex technologies, namely a combination of electric arc spraying (EA) and High-Velocity-Oxy-Fuel (HVOF) flame spraying. The coatings are realized in this way can make a layer thickness of up to several $\mathrm{mm}$. They are usually realized as three-layer. Composition: substrate, intermediate layer (NiTi), filling layer (13\% Cr steel), and final layer (WCCo). The coatings made in this way were tested by metallographic and selected mechanical tests. The achieved results significantly expand the possibilities of using standard thermal coatings.
\end{abstract}

Keywords: Thermal spraying, HVOF, mechanical property, testing methods

\section{INTRODUCTION}

Thermal spraying is one of the modern production and renovation technologies. Thermal spraying is a process where the coating materials are melted and with kinetic energy, the particles are impacted onto the substrate surface to be coated. The coating material is propelled on the substrate using a stream of gas or compressed air depending on the thermal sparing process being used, creating a surface structure on a given substrate. There are a number of technologies currently available. The most common division is according to the type of energy used, its maximum temperature, the type of additional material used. The combination of the used energy, temperature, types of coating materials can achieve a number of specific properties of the produced coatings, such as resistance to abrasion, thermal barrier corrosion, and more [1]. Each spraying technology has a certain specific range of resulting parameters such as maximum coating thickness, coating type, resulting properties such as porosity, adhesion, hardness. This paper deals with coatings made by two technologies, namely electric arc spraying and HVOF. The total thickness of the combined spray coatings ranged from a typical 0.5 to an extreme $1.5 \mathrm{~mm}$. A comparison of different thermal spray processes is given in Table $1[1,2]$.

\section{MATERIALS AND TECHNOLOGY USED}

A standard Praxair TAFA $8830 \mathrm{MHU}$ device was used to make the base layer and the filling layer of the coating. A Tafa JP 8000 device was used for the top layer. The coatings were sprayed with the above equipment with a standard preparation procedure on a carbon steel blasted substrate (S355). To design the set of the spaying parameters, the parameters recommended by the powder producer were used as a reference. The chemical composition of the materials used is given in Tables 2-4. 
Table 1 Comparison of different thermal spray processes $[1,2]$

\begin{tabular}{|c|c|c|c|c|c|c|}
\hline Type of System & $\begin{array}{c}\text { Flame or Plasma } \\
\text { Exit Temperature } \\
\left({ }^{\circ} \mathrm{C}\right)\end{array}$ & $\begin{array}{c}\text { Heat Transfer } \\
\text { or Substrate } \\
\left({ }^{\circ} \mathrm{C}\right)\end{array}$ & $\begin{array}{c}\text { Particle Impact } \\
\text { Velocity } \\
(\mathrm{m} / \mathrm{s})\end{array}$ & $\begin{array}{c}\text { Oxide } \\
\text { Content } \\
(\%)\end{array}$ & $\begin{array}{c}\text { Porosity } \\
(\%)\end{array}$ & $\begin{array}{c}\text { Adhesion (Bond } \\
\text { Strength) } \\
(\mathrm{MPa})\end{array}$ \\
\hline Detonation Gun & 3000 & $20-150 \mathrm{MAX}$ & $800-1000$ & 0.1 & $0.1-1.0$ & 82 \\
\hline HVOF & $2500-3100$ & $500-700$ & $500-800$ & 0.2 & $1.0-10$ & 68 \\
\hline Plasma Spraying & $5500-8300$ & $700-1000$ & $200-600$ & $0.1-1.0$ & $1.0-10$ & $90-95$ \\
\hline Wire Arc & $4000-6000$ & $500-800$ & 240 & $0.5-3$ & $10-20$ & $10-40$ \\
\hline Flame Spraying & $2500-3000$ & $500-700$ & $30-180$ & $4-6$ & 10 & $7-18$ \\
\hline
\end{tabular}

Table 2 Chemical composition WC-Co 88/12 HVOF

\begin{tabular}{|c|c|c|c|}
\hline $\begin{array}{c}\mathrm{W} \\
\mathrm{wt}(\%)\end{array}$ & $\begin{array}{c}\mathrm{Co} \\
\mathrm{wt}(\%)\end{array}$ & $\begin{array}{c}\mathrm{C} \\
\mathrm{wt}(\%)\end{array}$ & $\begin{array}{c}\mathrm{Fe} \\
\mathrm{wt}(\%)\end{array}$ \\
\hline base & $10,5-13$ & $5,2-5,6$ & 0,20 \\
\hline
\end{tabular}

Table 3 Chemical composition anchor layer, wire NiTi

\begin{tabular}{|c|c|c|}
\hline $\begin{array}{c}\mathrm{Ni} \\
\mathrm{wt}(\%)\end{array}$ & $\begin{array}{c}\mathrm{Ti} \\
\mathrm{wt}(\%)\end{array}$ & $\begin{array}{c}\text { Other } \\
\mathrm{wt}(\%)\end{array}$ \\
\hline base & 3,3 & 0,9 \\
\hline
\end{tabular}

Table 4 Chemical composition filling layer, wire $\mathrm{Fe} 13 \mathrm{Cr}$

\begin{tabular}{|c|c|c|c|c|c|}
\hline $\begin{array}{c}\mathrm{Fe} \\
\mathrm{wt}(\%)\end{array}$ & $\begin{array}{c}\mathrm{Cr} \\
\mathrm{wt}(\%)\end{array}$ & $\begin{array}{c}\mathrm{Ni} \\
\mathrm{wt}(\%)\end{array}$ & $\begin{array}{c}\mathrm{Mn} \\
\mathrm{wt}(\%)\end{array}$ & $\begin{array}{c}\mathrm{C} \\
\mathrm{wt}(\%)\end{array}$ & $\begin{array}{c}\mathrm{S} \\
\mathrm{wt}(\%)\end{array}$ \\
\hline base & 13 & 0,5 & 0,5 & 0,35 & 0,25 \\
\hline
\end{tabular}

\section{SAMPLE PARAMETERS}

To verify the properties of double sprays, three types of samples with different thicknesses of the filling layer were made. The technologies used and the thicknesses of the individual layers are listed in Table 5. Figure 1 shows the macrostructures and thicknesses of the individual samples. The measured values correspond to Table 5. No unacceptable defects such as cracks or delamination of the layers were observed.

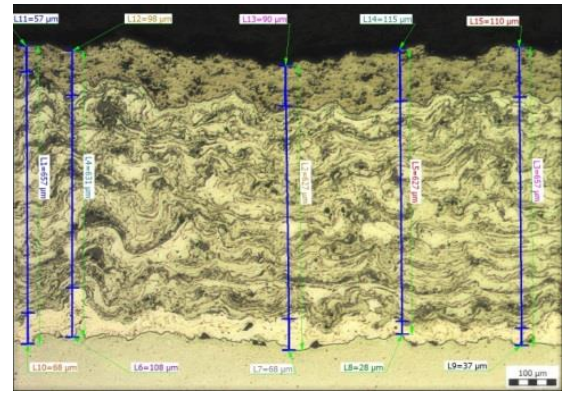

a)

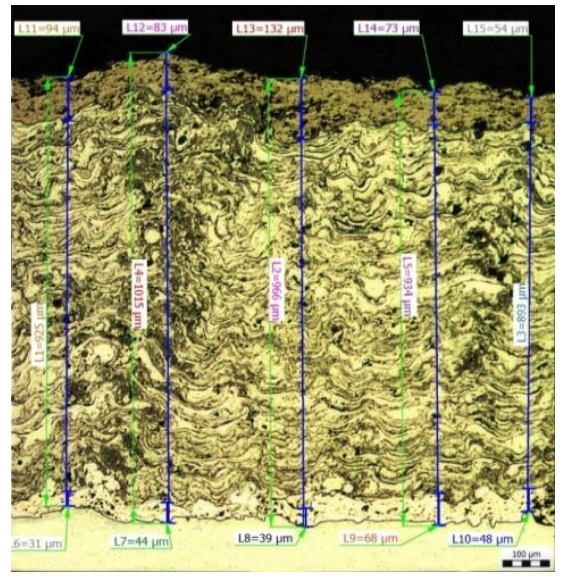

b)

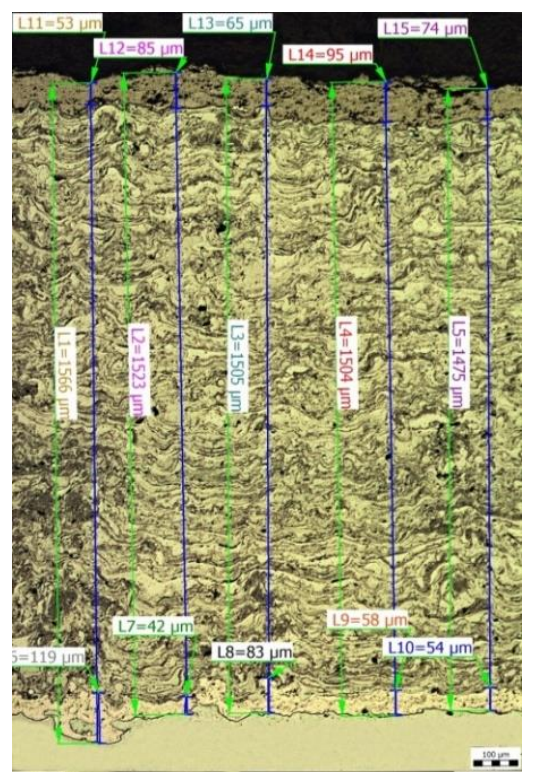

c)

Figure 1 Layer thickness measurement a) sample no.1, b) sample no.2, c) sample no.3 
Table 5 Sample parameters

\begin{tabular}{|c|c|c|c|c|c|c|}
\hline Sample & $\begin{array}{c}\text { Background } \\
(\mathrm{EA})\end{array}$ & $\begin{array}{c}\text { Thickness } \\
(\mathrm{mm})\end{array}$ & $\begin{array}{c}\text { Filling } \\
(\mathrm{EA})\end{array}$ & $\begin{array}{c}\text { Thickness } \\
(\mathrm{mm})\end{array}$ & $\begin{array}{c}\text { Cover } \\
\text { (HVOF) }\end{array}$ & $\begin{array}{c}\text { Thickness } \\
(\mathrm{mm})\end{array}$ \\
\hline 1 & $\mathrm{NiTi}$ & 0,05 & $13 \% \mathrm{Cr}$ & 0,5 & WC-Co & 0,15 \\
\hline 2 & $\mathrm{NiTi}$ & 0,05 & $13 \% \mathrm{Cr}$ & 1 & WC-Co & 0,15 \\
\hline 3 & $\mathrm{NiTi}$ & 0,05 & $13 \% \mathrm{Cr}$ & 1,5 & WC-Co & 0,15 \\
\hline
\end{tabular}

\section{SAMPLE PARAMETERS AND PROPERTIES TESTING}

The prepared samples according to Table No. 5 were tested by a standard range of tests for thermal spraying [3]. Metallography and hardness measurements were performed on all samples. Sample No. 2 was subjected to a torsion test and adhesion test according to ASTM C633 -13 [4,5]. Figure 2 shows the macrostructure of the sprayed layer (2a), typical transitions at the substrate/anchor layer interface (2b), and the filler and cover layer transition (2c). Figure 3 shows the hardness test according to Vickers HV0.1 performed in individual parts of coatings. The achieved values correspond to the materials used. In the topcoat, it is above 1300 HV0.1, 440 HV0.1 in the infill, 155 HV0.1 in the anchor layer. The plastic properties of the coatings are evaluated by bending and torsion tests. We tested the coatings using a torsion test. If the thickness of the coatings is greater than the commonly used $0.2 \mathrm{~mm}$, it is necessary to modify the evaluation criteria. With a coating thickness of up to $1.2 \mathrm{~mm}$, it was possible to stress the sample with a torque of $+90^{\circ}$. At torsion to 90, the coating delamination has occured, see Figure 4 and Figure 5.

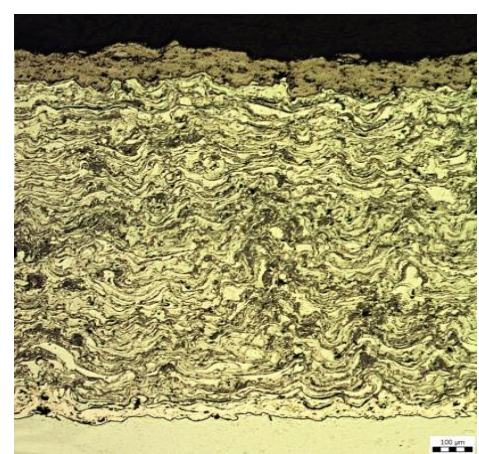

a)

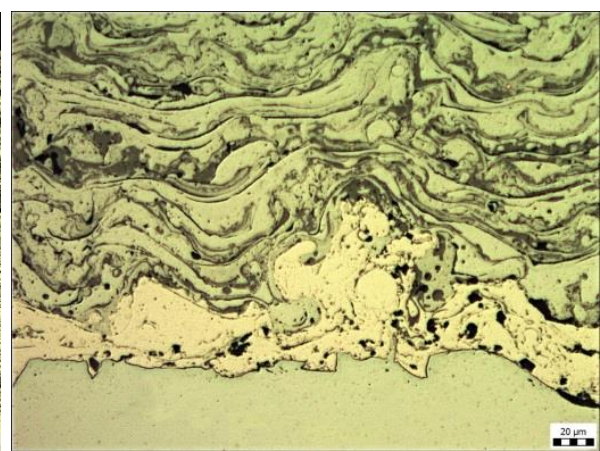

b)

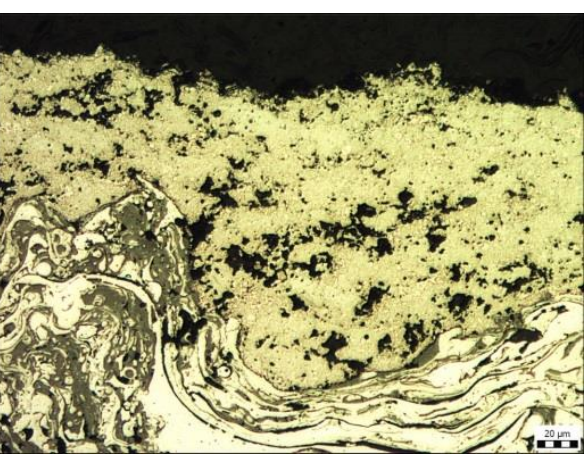

c)

Figure 2 Metallography sample no.1 a) macrostructure, b) substrate/NiTi interface c) interface filling $13 \mathrm{Cr} /$ WC-Co

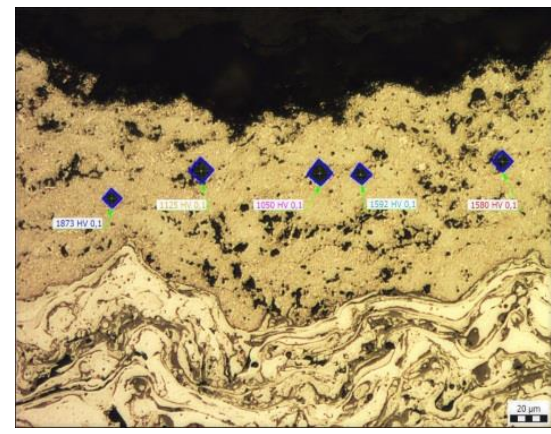

a)

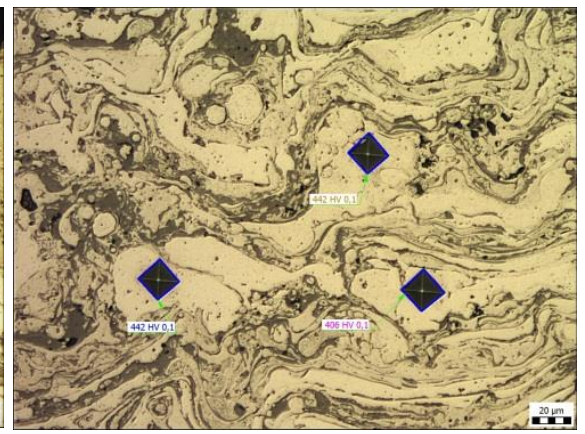

b)

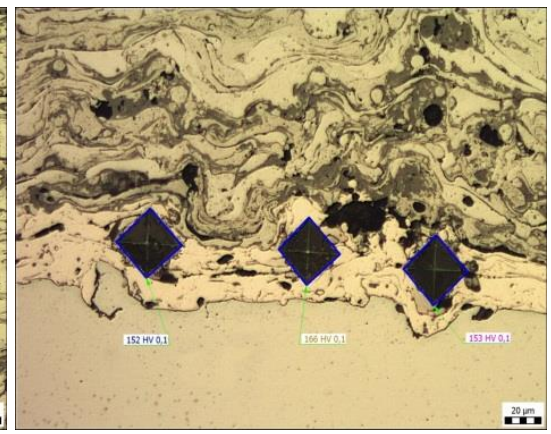

c)

Figure 3 Hardness sample no.1 a) surface, b) infill, c) anchor layer 


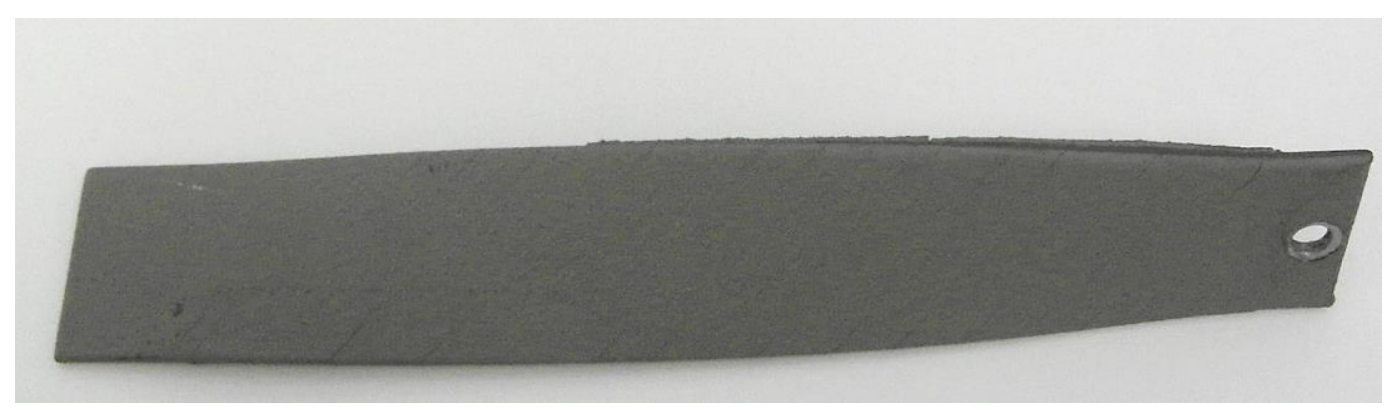

Figure 4 Torsion test samples no. 2(+90 -satisfactory)

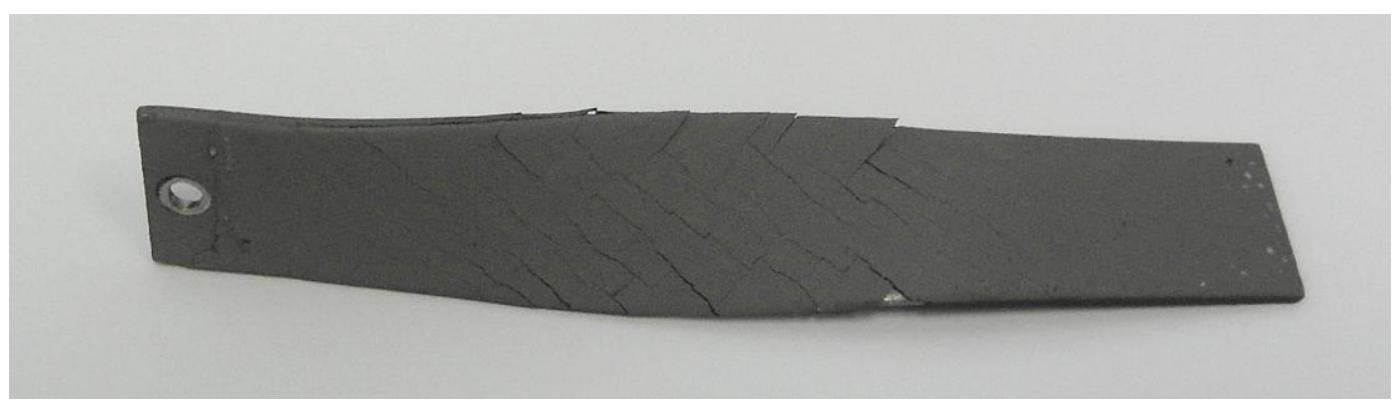

Figure 5 Torsion test samples no. $2\left(+90^{\circ},-90^{\circ}\right.$ - unsatisfactory, delamination of the spray from the substrate)

Coating adhesion strength was measured following procedures dictated by ASTM C633. A commercial adhesive (HTK Ultra Bond 100) was used to bond the coating face and the grit-blasted encounter button, followed by curing for $80 \mathrm{~min}$. at $150{ }^{\circ} \mathrm{C}$. After curing, samples underwent tensile loading using a servohydraulic tensile testing machine with a static $200-\mathrm{kN}$ load cell at $1 \mathrm{~mm} / \mathrm{min}$ until the failure condition was reached (separation between fixture buttons). If the sample failed at the coating/substrate interface, the measurement was considered valid for adhesion strength determination. For each condition, the adhesion strength values were averaged from three measurements. The average values of Adhesion (Bond Strength) from the three samples for each sample were around 35-40 MPa, which is at the upper limit of the technology used. The damage occurred in a layer sprayed with an electric arc. The maximum adhesion of combined coatings will be limited by the "weakest technology" in our case by electric arc spraying.

\section{CONCLUSION}

This paper deals with the properties of coatings anchored by two different technologies, namely a combination of electric arc spraying (EA) and high-velocity-ox-fuel flame spraying (HVOF). This combination can be interesting when it is necessary to make a coating of greater thickness and the use of exclusively HVOF technology may be inefficient or technically impossible. The results show that the possible and effective use of two different thermal spraying technologies. However, the resulting properties are limited by the worst, which may not be a limiting parameter for use in practical applications in industry.

\section{ACKNOWLEDGEMENTS}

This paper was created in Faculty of Mechanical Engineering within student grants projects SV3451X41 supported at the VŠB-TU Ostrava by the Ministry of Education of the Czech Republic.

\section{REFERENCES}

[1] DAVIS, Joseph R., et al. (ed.). Handbook of thermal spray technology. ASM international, 2004. 
[2] TALIB, R. J., et al. Thermal spray coating technology: a review. Solid State Sci Technol. 2003, vol. 11, no. 1, pp. 109-117.

[3] OCHODEK, Vladislav. Evaluation of selected characteristics of HVOF Coatings. In: Metal 2018, 27th International Conference on Metallurgy and Materials. 2018, p. 1194-1197.

[4] ASTM C633 - 13 Standard Test Method for Adhesion or Cohesion Strength of Thermal Spray Coatings. West Conshohocken: ASTM International, 2017.

[5] GREVING, D. J.; SHADLEY, J. R.; RYBICKI, E. F. Effects of coating thickness and residual stresses on the bond strength of ASTM C633-79 thermal spray coating test specimens. Journal of Thermal Spray Technology. 1994, vol. 3 , no. 4 , p. 371 . 